\title{
Geological Setting, Compositional and Economic Appraisal of Clay-Shale Occurrence in Itu-Mbonuso/Iwere Area, South-Eastern Nigeria
}

\author{
Olugbenga Okunlola ${ }^{1} \&$ Christopher Egbulem ${ }^{2}$ \\ ${ }^{1}$ Department of Geology University of Ibadan, Nigeria \\ ${ }^{2}$ Nigerian Geological Survey Agency, Abuja, Nigeria \\ Correspondence: Olugbenga Okunlola, Department of Geology University of Ibadan, Nigeria, E-mail: \\ gbengaokunlola@yahoo.co.uk
}

Received: September 27, 2014

Accepted: November 4, $2014 \quad$ Online Published: February 28, 2015

doi:10.5539/jgg.v7n1p85

URL: http://dx.doi.org/10.5539/jgg.v7n1p85

\begin{abstract}
The clay-shale bodies of Itu-Mbonuso/Iwere area occur in blankets within the first half of a metre from the surface in most places. They are medium to dark gray.

To assess their potentials as raw materials for industrial usage in the manufacture of Ceramics, Cement, Structural, Refractory bricks and pottery wares, the representative samples were subjected to mineralogical, chemical analyses using Inductive Coupled Plasma Spectrometer and X-Ray Diffraction respectively, while geotechnical properties tests were carried out on grain size distribution, sedimentation, Atterberg Limits and firing tests in the laboratories.

Mineralogical analysis revealed that kaolinite is the major clay mineral with a range of $18.17-55.09 \%$ and 6.95 -38.76 in the clay and shale respectively.

$8 \%$; smectites ranges from $10.62-12.72 \%$ and $4.94-10.84 \%$ in the clay and shale respectively. Palygorskite occurs in one sample only at $53.99 \%$. The non-clay mineral is quartz and ranges between $34.24-81.17 \%$ and $51.93-55.28 \%$ in clays and shale respectively.

Chemical analysis showed that the average $\mathrm{Si}_{2} \mathrm{O}$ content is $53.10 \%$ and $49.92 \% ; \mathrm{Al}_{2} 0_{3}, 18.81 \%$ and $18.15 \%$; $\mathrm{Fe}_{2} \mathrm{O}_{3}, 8.25 \%$ and $6.63 \% ; \mathrm{MgO}, 1.59 \%$ and $3.72 \% ; \mathrm{TiO}_{2}, 1.43 \%$ and $1.49 \%$ for clay and shale respectively; while other oxides $\mathrm{Na}_{2} \mathrm{O}, \mathrm{K}_{2} \mathrm{O}, \mathrm{MnO}$, and $\mathrm{P}_{2} \mathrm{O}_{5}$ are less than $1 \%$ each. The three oxides silica, alumina and iron oxide account for $80.16 \%$ and $74.70 \%$ of the bulk chemical composition of the clay and shale respectively. The average AR is 2.38 and 2.78, while the SR is 1.92 and 2.04 for the clay and shale respectively. The chemical compositions of the clay-shale compare favourably with some sedimentary clays and shale within the Nigerian Sedimentary basins.
\end{abstract}

Results of grain size and sedimentation analyses showed that the fine fraction ranges from 84.40 to $96.40 \%$ while the clay-size fraction range from 36 to $76 \%$ in the clay- shale.

About $76 \%$ of the representative samples have clay size fraction between 50 to $76 \%$. Atterberg limits tests indicated that the studied clay-shale have wide range of liquid limits (47.7 to $194.0 \%)$, plastic limits (22.2 to $77.7 \%$ ), and plastic indices (15.8 to $116.3 \%)$. Plasticity results indicated that the clays and shale are majorly inorganic clay of medium to high compressibility, a few organic silt of medium plasticity and organic silt or clay of high plasticity and compressibility.

Firing test result indicated that the colour change is from greyish through orange to light Brown. Other physical parameters include water absorption capacity $(10.12-13.4 \%)$; firing shrinkage $(4.8-9.1 \%)$ loss on ignition (9.50-14.98\%) and plasticity indices of $15.78 \%-77.3 \%$ and 16.7 and $116.3 \%$ for the clays and shale respectively.

On the basis of the chemical compositions the clay-shale is suitable for use in the manufacture of good quality cement and structural wares, while $95 \%$ of the representative samples having plastic limits between 22.3 and $57.5 \%$ are suitable for the production of ceramics, pottery and wall bricks. Adequate processing and proportional mixing in specified ratio with fine sand would reduce the firing shrinkage to an acceptable limit. Improving or upgrading of the alumina content by the addition of pure alumina or blending with clay of high alumina content 
can improve the refractory characteristics of the clay-shale.

Keywords: Itu-Mbonuso, Iwere area occur, clay-shale, sedimentary clays, shale, Sedimentary basins

\section{Introduction}

Clay is one of the oldest building materials among other ancient naturally occurring geologic materials such as stones. Clays as minerals and rocks are generally common and may be found in all geologic environments. Their types, nature of occurrence, chemical and mineralogical composition as well as their relative abundance and uses are more often the subject of study. In developed and developing countries industrial minerals of which clay is part, are very important for industrial and domestic usage. Their utility can generate a lot of economic development and employment.

In Nigeria numerous clay-shale deposits occur in all sedimentary basins, while residual clay deposits are also common in the basement complex, particularly in the south-western states. Clays are important raw materials for modern and cottage industries. However, in Nigeria clay deposits have not been adequately utilized considering the quality and quantity that occur all over the country. Underutilization of the clay deposits may be attributed to insufficient geological information on the assessment of the properties of the various clay deposits on one hand and shallow knowledge of what each deposit could be used for on the other hand (Okunlola, 2008). It is important therefore that investigations of clay deposits occurring all over Nigeria be carried out to assess their suitability for various industrial purposes so as to conserve the scarce foreign exchange. In addition to this, assessment of industrial minerals occurring in Nigeria will contribute to geo-database that could assist potential investors. The end result will be creation of employment. The present study is therefore a contribution to the evaluation of clay-shale deposit in Itu-Mbonuso/Iwere area of Ini Local Government of Akwa-Ibom State.

\section{Geological Setting}

In the pre-Cretaceous times, Nigeria consists of uplifted continental landmass made up of pre-Cambrian basement rocks which are now uncomfortably overlain by Cretaceous sediments in the basinal area (Kogbe, 1975). The Nigeria geological terrain consists of Basement Complex and seven sedimentary basins: Sokoto, Bida (or Mid-Niger) Benue, Anambra, Chad dahomey and the Niger Delta basins (Figure 1). According to Burke et al., (1970, 1971) and Grant (1971), the sedimentary basin of the eastern Nigeria originated as a triple junction. Burke et al., (1970, 1971) had proposed an R R R (ridge-ridge-ridge) triple junction model, which appears to account more satisfactorily for the present arrangement of transform fracture zone in the Gulf of Guinea region. It is now generally agreed that the Benue trough was part of an RRR triple junction systems in which the arms developed at different rates. The southern arm of this trough was first to develop during the separation of South America and Africa. This led to the accumulation of sediments in the Early Cretaceous. The sedimentary sequences of this rift basin consist of three major unconformity - bounded depositional successions: Abian to Cenomenian; Turonian to Coniacian; and Campanian to Maastrichtian. During the Coniacian the onset of active tectonic activities started with rapid facies changes (Short and Stauble, 1967). This culminated into an uplift in which the Abakliki anticlinorium was formed. This uplift resulted into two depositional depressions flanking the anticlinorium which to the north-west is Anambra basin and to the south-east is the Afikpo Syncline. These two basins became the depo-centres during the Campanian to Paleocene. The study area is in the south-easternmost edge of Anambra basin and is underlain by Imo Shale. The Imo Shale is a dark gray to bluish gray shale interbedded with thin sandstone bands. The upper parts grade into clay-shale, then into siltstone and sandstone capping. 


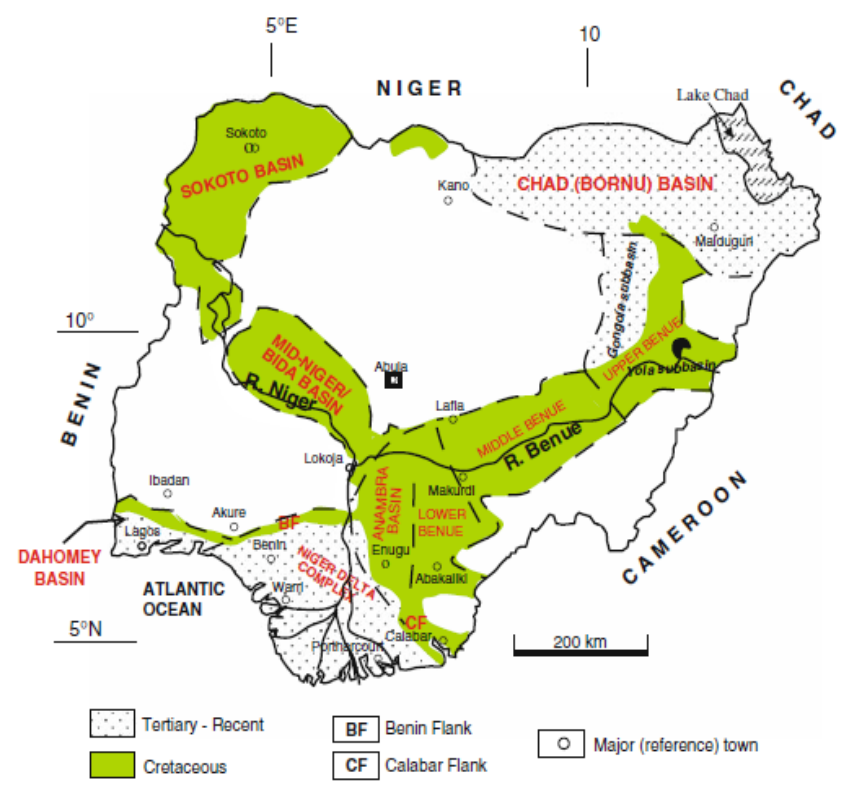

Figure 1. Geological map of Nigeria (after Obaje, 2009) showing location of project area

The study area is located in the south-eastern Nigeria (Akwa-Ibom) at about $30 \mathrm{~km}$ north of Ikot-Ekpene, comprising Ikpe Ikot-Nkon, Itu-Mbonuso, Iwere, Ebam-Ikot, and Obotme communities

Geology of Study Area: The study area is underlain by the Imo formation which consists of thick clayey shale, fine textured dark grey to bluish gray shale and thin sandstone bands. The type locality is situated along the Imo River between Umuahia and Okigwe in the south-eastern Nigeria (Simpson, 1954). The studied area lies in the south-easternmost edge of Anambra basin, in Ini local government area of Akwa-Ibom state. It consists of two main rock types which are Clay/shale and sandstone (Figure 4).

Shale: The shale is bluish to dark gray in colour. It is fissile and flat lying. The upper part grades into admixture of clay and shale and finally into light brownish gray to reddish brown clay. Observation from gullies shows that the clay-shale sequence is over five metres thick. The clay portion is between 1 to 1.5 metres thick in places, becoming silty clay in some localities. Carbonized streaks of plant remains are locally present in the dark gray portion of the shale particularly in the area towards the boundary between Akwa-Ibom and Abia State. Pebbles, boulders and lenses of limestone are common in the clay portion particularly in the south eastern portion of the area.

Sandstone: The sandstone is essentially massive over 6 to 8 metres in some exposures particularly around Ebo, Okpoto and Iwere area in the north and southern portion respectively. It is characterized by fine lamination probably as a result of grading and streaks of whitish clay (kaolin). It is generally friable and whitish beyond the laterized portions. Texturally it is medium to coarse grained and fining upwards. This order is repeated along the column. No bedding occurs in the basal part; however, towards the upper portion one or two sequences of indurate, well bedded portions are sandwiched in the massive. The thickness of the basal bed in the sequence is about $7 \mathrm{~cm}$ but the successive beddings decrease to fine laminations. In some places very fine beds of about 2 to $3 \mathrm{~mm}$ were common above the indurate sequences. The dip of the beds is about $2^{\mathrm{O}} \mathrm{NW}$. The basal portion is characterized by numerous bioturbations. Southwards, the sandstone becomes more gravelly. In some locations about $4 \mathrm{~km}$ from the study area the sandstone is being mined for sand and gravel. In the study area the elongated and rounded hills, are capped by outliers of sandstone. It is likely that it has been eroded in those portions where the clay and shale are now exposed. 


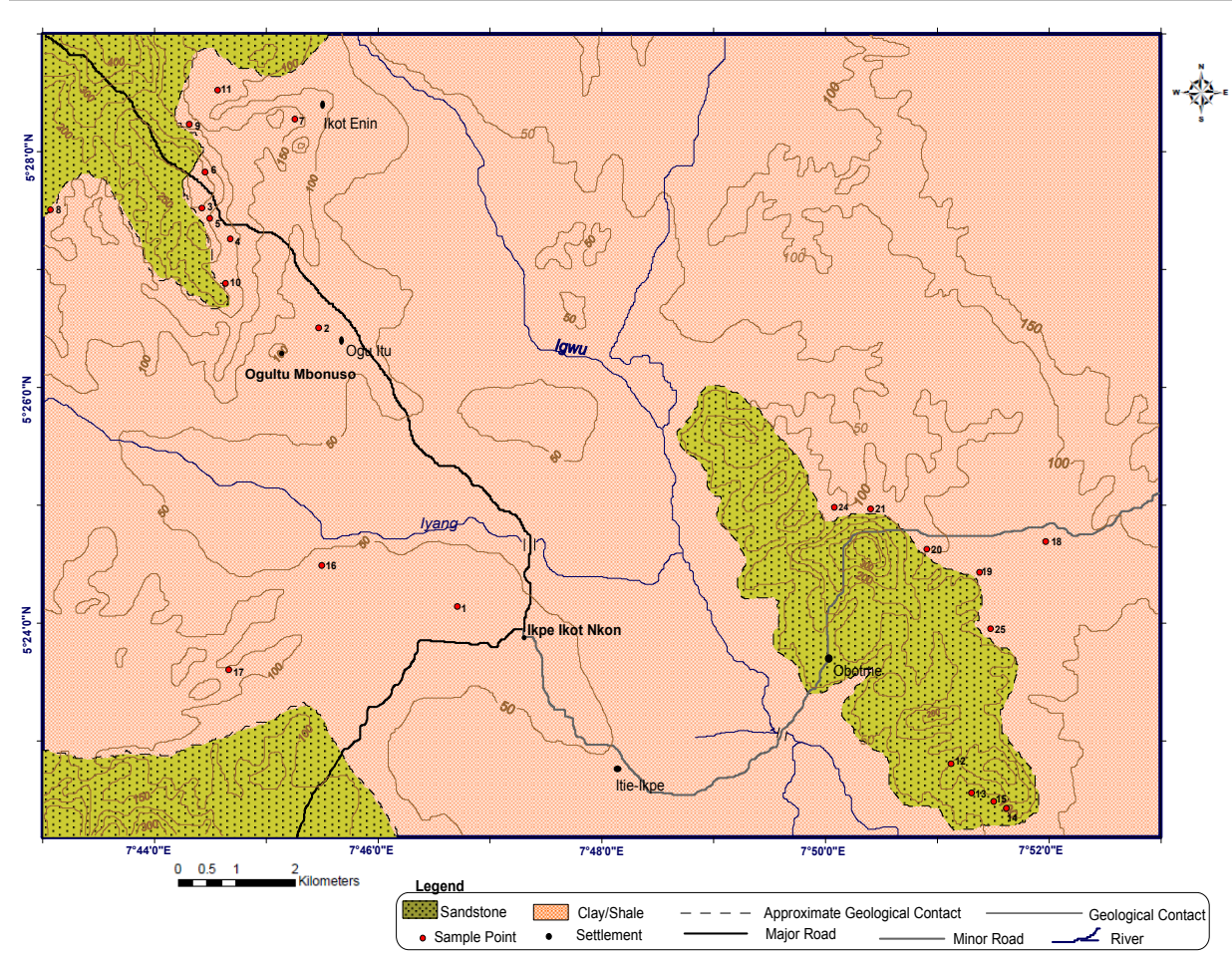

Figure 2. Geological map of study area showing sample locations

\section{Method of Investigation}

Sampling and mapping was systematically carried out simultaneously using Etrex Global Positioning System (GPS) receiver to mark sample locations and lithological boundaries. Sampling was made within intervals of 500 $\mathrm{m}$ to $1 \mathrm{~km}$ (where possible) along erosion channels, river channels, excavations and over places where clay/shale is not far from the surface. The samples were collected from Ikpe Ikot-Nkon, Itu-Mbonuso, Ebo, Ebam -Ikot, Okpoto and Iwere areas. Sampling was carried out by pitting with shovel and digger. The collected samples were each tied up in a polythene bag and kept in a sample bag and labelled. They were finally air dried and pulverized before the various analyses and tests were carried out. Total of 18 samples out of 25 collected in the field were air dried and pulverized for various analyses and tests.

Mineralogical analysis was carried out at Acme Laboratory Canada, using X-ray Diffractometer. The resulting curves were interpreted by comparing peaks of notable intensities with those of Joint Committee on Powder Diffraction Standard (JCPD), 1974 and that of clay minerals documented by Carol (1970).

Chemical analysis was carried out on thirteen (13) samples at Acme laboratory using Inductive Coupled plasma Spectrometer (ICP-MS). The analyses were carried out for eleven major oxides- $\mathrm{SiO}_{2}, \mathrm{Al}_{2} \mathrm{O}_{3}, \mathrm{Fe}_{2} \mathrm{O}_{3}, \mathrm{MgO}, \mathrm{CaO}$, $\mathrm{Na}_{2} \mathrm{O}, \mathrm{K}_{2} \mathrm{O}, \mathrm{TiO}_{2}, \mathrm{P}_{2} \mathrm{O}_{5}, \mathrm{MnO}$ and $\mathrm{Cr}_{2} \mathrm{O}_{3}$.

Physical test was carried out on eighteen (18) samples. The tests include Atterberg Limits (Liquid, Plastic Limits and plasticity Indices), Firing test (Linear Shrinkage, Water Absorption Capacity and Loss on Ignition). Other physical tests are: Specific gravity, Bulk density, Natural moisture content and $\mathrm{pH}$. These tests were carried out at the geotechnical laboratory, Federal University of Technology, Akure, Nigeria.

\section{Results and Discusions}

Typical X-ray Diffractogram of the Clay-Shale samples are presented in Figures 3a-b and modal mineralogical values in table 1 . These diffractograms were compared with the established standard and they were interpreted with reference to Joint Committee on Powder Diffraction Standards (JCPDS), (1974) and that of clay minerals documented by Carol, (1970).

The results indicated that the clay mineral assemblage consists of Kaolinite, Smectites (nontronite and montmorillonite) and palygorskite. The most dominant and widely distributed clay mineral is the kaolinite, followed by small amount the smectites. The averages of the clay minerals are $30.19 \%$ (kaolinite), $7.82 \%$ (smectites) and $10.80 \%$ palygorskite. Quartz is the dominant non-clay mineral with an averages of $49.67 \%$ while 
others are about $1.39 \%$. The XRD diffractograms showed kaolinite had conspicuous intensities at $2 \varnothing$ equals to $12.4^{\circ}, 25^{\circ}, 39.5^{\circ}$ and $21.2^{\circ}$; Montmorillonite at $5.9^{\circ}, 6.5^{\circ}$ and $20.4^{\circ}$; Palygorskite at $8.8^{\circ}, 13.94^{\circ}, 16.5^{\circ}$ and $27.9^{\circ}$; Quartz at $20.5^{\circ}, 26.7^{\circ} 20.85^{\circ}, 26.7^{\circ}, .50 .4^{\circ}, 60.4^{\circ}$ and $68.4^{\circ}$; while Nontronite reflects at $6.0^{\circ}, 19.5^{\circ}$ and $35.2^{\circ}$.

The results of the XRD showed that the clay and shale in Iwere area is richer in kaolinite, \{sample numbers 021(clay) and 024(shale) $\}$ than the Clay-Shale in Itu-Mbonuso area (sample numbers 010(clay) and 011(shale)\} table1. Grim, 1962 has shown that large amount of kaolin (over 35\%) make clay product more ornamental. This shows that the Iwere Clay-Shale is much better than the Itu-mbonuso Clay-Shale
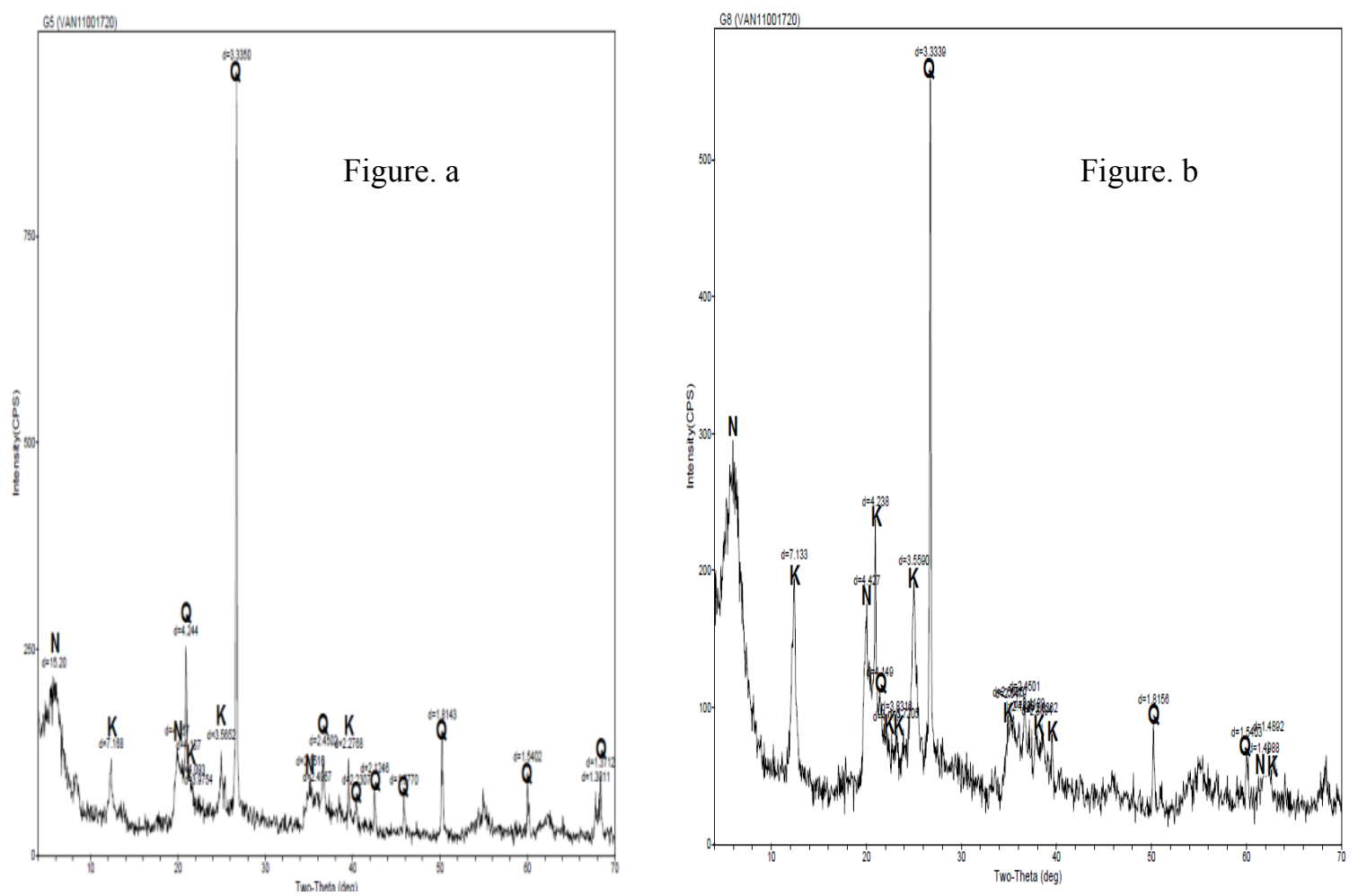

Figure 3. a, b showing typical XRD peaks for the shale and clay samples respectively

$\mathrm{N}=$ Nontrinite; $\mathrm{K}=$ Kaolinite; $\mathrm{Q}=\mathrm{Quartz}$; Montmorillonite; $\mathrm{P}=$ Palygorskite.

Table 1. Mineralogical Composition of Clay-Shale in Itu-Mbonuso/Iwere Area

\begin{tabular}{llllll}
\hline Sample code & Quartz \% & Kaolinite & Palygorskite & Smectite \% & Others \\
\hline IG 010(clay)Figure 4a & 55.28 & 32 & - & 12.72 & - \\
011 (shale)Figure 4b & 25.71 & 6.95 & 53.99 & 10.84 & 2.51 \\
020clayey sand) & 81.17 & 18.17 & - & - & - \\
Figure 4c & & & & & \\
021 (clay)Figure 4d & 34.24 & 55.09 & - & 10.62 & 0.05 \\
024 (shale) Figure4e & 51.93 & 38.76 & - & 4.94 & 4.37 \\
Average & 49.67 & 30.19 & 10.80 & 7.82 & 1.39 \\
\hline
\end{tabular}

\section{Geochemical Features}

The chemical compositions of the clay-shale are presented in table 2.

The chemical analysis revealed the predominance of $\mathrm{SiO}_{2}(48.27-61.82 \%)$ in the clays and $(47.85-52.72 \%)$ in the shale. The $\mathrm{Al}_{2} \mathrm{O}_{3}$ content for clays ranges from $14.77-22.28 \%$ while for the shale it is between $15.02-$ $20.37 \%$. The average Silica / Alumina ratio for both clays and shale are 2.82 and 2.75 respectively. This ratio clearly defines the clays and shale to be aluminous-silicates. The average $\mathrm{SiO}_{2}$ content of both clays and shale are $53.10 \%$ and $49.92 \%$, while that of $\mathrm{Al}_{2} \mathrm{O}_{3}$ are $18.81 \%$ and $18.15 \%$ respectively. This indicates that the clays 
and shale are of low quality refractory varieties. Generally the higher the alumina content the higher the quality of the refractory product. The Silica and Alumina ratios (SR and AR respectively) of the studied clay-shale (table 2), vary from SR: (1.19-2.93), AR: (1.66-3.50) for clays, while SR and AR for shale vary from $1.77-2.44$ and $2.23-3.19$ respectively. These ratios are within the range of SR: 1.5-4.00 and AR: $1.4-3.50$ that is considered favourable for clay-shale utilization in the manufacture of structural wares and cement (Abatan et, al, 1993). These two oxides $\left(\mathrm{SiO}_{2}\right.$ and $\left.\mathrm{Al}_{2} \mathrm{O}_{3}\right)$ constitute the bulk $(71.91 \%$ and $68.07 \%$ respectively) of the chemical compositions.

The chemical impurities of $\mathrm{Fe}_{2} \mathrm{O}_{3}$ and $\mathrm{TiO}_{2}$ in the Itu-Mbonuso/Iwere clay-shale are significant (average of $8.25 \%$ and $6.63 \%$ in the clay and shale respectively). The high concentration of the iron oxide gave rise to the orange to light brown colour on firing. This firing colour is undesirable in paper and some ceramic industries, but is acceptable in the manufacture of low quality wall tiles, structural wares (such as roofing tiles, wall bricks) and pottery. Akpokodje et al, (1991 has reported that most of the south-eastern Nigerian clays contain much higher amount of iron and titanium oxides and that the proportions of these oxides are higher in swamp clays and in the weathering upper regolith of the various deposits, while the high content of iron and titanium oxides decrease with depth where tropical weathering drastically diminishes. Other chemical impurities include $\mathrm{MgO}$ (1.04- 2.99\% and 2.00-5.70\% in clay and shale respectively); while $\mathrm{CaO}, \mathrm{Na}_{2} \mathrm{O}, \mathrm{K}_{2} \mathrm{O}, \mathrm{P}_{2} \mathrm{O}_{5}, \mathrm{MnO}, \mathrm{Cr}_{2} \mathrm{O}_{3}$ are less than one percent each. These later oxides $\left(\mathrm{MgO} \mathrm{CaO}, \mathrm{Na}_{2} \mathrm{O}, \mathrm{K}_{2} \mathrm{O}\right)$ which are fluxes will reduce the vitrification of the clay-shale in its use in as refractory raw material, but will enhance the manufacture of Bricks and Pottery ware as a result of early vitrification and energy conservation.

Comparatively, the clays and shale are chemically similar in all their various component oxides, except that the clays contain more iron oxide than the shale. This probably is because the clay is nearer the upper weathering zone as noted by Akpokodje et.al. On the other hand, the shale contains more Magnesia $(\mathrm{MgO})$ than the clay (Average of $3.72 \%$ and $1.59 \%$ respectively).

Table 2. Chemical Compositions various samples of Studied Clay and Shale

\begin{tabular}{|c|c|c|c|c|c|c|c|c|c|c|c|c|c|}
\hline Sample Code & $001+$ & $003 \mathrm{~A}+$ & $009+$ & $010+$ & $012+$ & $019+$ & $020+$ & $021+$ & $005^{*}$ & $011^{*}$ & $016^{*}$ & $018^{*}$ & $024 *$ \\
\hline $\mathrm{SiO}_{2}$ & 50.14 & 52.85 & 49.18 & 52.89 & 48.27 & 60.16 & 61.82 & 49.48 & 48.52 & 49.56 & 50.94 & 47.85 & 52.72 \\
\hline $\mathrm{Al}_{2} \mathrm{O}_{3}$ & 22.28 & 21.15 & 17.24 & 16.62 & 20.88 & 15.69 & 14.77 & 21.79 & 19.57 & 15.02 & 18.14 & 20.37 & 17.62 \\
\hline $\mathrm{Fe}_{2} \mathrm{O}_{3} \%$ & 8.35 & 6.05 & 9.52 & 10.03 & 11.19 & 7.92 & 6.33 & 6.81 & 7.82 & 5.32 & 5.73 & 6.39 & 7.91 \\
\hline $\mathrm{MgO} \%$ & 1.04 & 1.31 & 2.99 & 2.06 & 1.26 & 1.01 & 1.15 & 1.86 & 3.28 & 5.78 & 4.47 & 3.13 & 2.00 \\
\hline $\mathrm{CaO} \%$ & 0.09 & 0.07 & 0.30 & 0.370 & 0.16 & 0.49 & 0.59 & 0.87 & 0.59 & 0.22 & 0.40 & 0.52 & 0.71 \\
\hline $\mathrm{Na}_{2} \mathrm{O} \%$ & 0.03 & 0.04 & 0.05 & 0.15 & 0.05 & 0.07 & 0.003 & 0.06 & 0.10 & 0.05 & 0.14 & 0.08 & 0.06 \\
\hline $\mathrm{K}_{2} \mathrm{O} \%$ & 0.47 & 0,62 & 0.55 & 0.68 & 0.69 & 0.64 & 0.64 & 0.94 & 0.95 & 0.69 & 0.89 & 0.94 & 1.23 \\
\hline $\mathrm{TiO}_{2} \%$ & 1.61 & 1.71 & 1.14 & 1.19 & 1.69 & 1.66 & 1.17 & 1.23 & 1.69 & 0.95 & 1.07 & 1.22 & 2.54 \\
\hline $\mathrm{P}_{2} \mathrm{O}_{5} \%$ & 0.20 & 0.10 & 0.08 & 0.12 & 0.09 & 0.10 & 0.06 & 0.08 & 0.07 & 0.07 & 0.10 & 0.16 & 0.09 \\
\hline $\mathrm{MnO} \%$ & 0.01 & $<0.01$ & 0.02 & 0.30 & 0.02 & 0.22 & 0.06 & 0.03 & 0.09 & 0.08 & 0.12 & 0.04 & 0.08 \\
\hline $\mathrm{Cr}_{2} \mathrm{O}_{3} \%$ & 0.025 & 0.022 & 0.021 & 0.019 & 0.019 & 0.017 & 0.015 & 0.017 & 0.020 & 0.018 & 0.024 & 0.020 & 0.019 \\
\hline LIO \% & 15.6 & 15.9 & 18.7 & 15.4 & 15.5 & 12.1 & 13.3 & 16.7 & 17.1 & 22.1 & 17.8 & 19.0 & 14.8 \\
\hline Total & 99.85 & 99.83 & 99.80 & 99.88 & 99.82 & 99.88 & 99.94 & 99.87 & 99.78 & 99.78 & 99.82 & 99.72 & 99.79 \\
\hline SR & 1.66 & 1.19 & 1.77 & 1.98 & 1.51 & 2.55 & 2.93 & 1.73 & 1.77 & 2.44 & 2.13 & 1.79 & 2.07 \\
\hline $\mathbf{A R}$ & 2.67 & 3.50 & 1.81 & 1.66 & 1.87 & 2.03 & 2.33 & 3.20 & 2.50 & 2.82 & 3.16 & 3.19 & 2.23 \\
\hline Mgo, +Cao & 1.13 & 1.38 & 3.29 & 2.43 & 1.42 & 1.50 & 1.74 & 2.73 & 3.87 & 5.92 & 4.87 & 3.65 & 2.71 \\
\hline $\mathrm{Na}_{2} \mathrm{O},+\mathrm{K}_{2} \mathrm{O}$ & 0.5 & 0.66 & 0.60 & 0.83 & 0.74 & 0.71 & 0.67 & 1.00 & 1.05 & 0.74 & 1.03 & 1.02 & 1.29 \\
\hline
\end{tabular}

In comparison with industrial specifications (table3), the clay-shale compares favourably with the specification for refractory Anon, (1972). However, the iron oxide in the studied clay is much higher than in the specification. Table 3 also shows that the specification for Brick clay (I):

Murray, (1960) compares favourably with the studied clay-shale in the project area, except that the soda and potash of the studied clay-shale are less than it is desirable in the specification. In general the clay-shale do not meet the specifications for Agricultural, $\backslash$ Pharmaceutical and Textile, however, the $\mathrm{SiO}_{2}, \mathrm{Na}_{2} \mathrm{O}, \mathrm{K}_{2} \mathrm{O}$ and $\mathrm{CaO}$ contents of the studied clay-shale compare favourably to what is required in the specification for the agricultural. While the Alumina falls short, the magnesia is higher.

Correlation of the clay-shale of the study area with other studied sedimentary clays/shale in Nigeria revealed that the studied clay-shale compare very closely with clay bodies in part of Eastern Dahomean Basin, (Nton M. E. 
and Elueze, 2005). There is a general conformity with this clay except that the $\mathrm{CaO}$ is much higher in the Dahomean basin while the $\mathrm{TiO}_{2}$ is far less than that of the study area. Other clays that compare very closely to the studied clay-shale are the Awo-Omamma (Akpokodje et al, 1991); Okada shale (Obrika, Osadebe and Onyeobi, 2007), however, the iron content of the studied clay-shale is very much higher than these.

Table 3. Chemical Compositions of Studied Clay-Shale Compared with some Clay/Shale in Nigeria and Industrial Specifications

\begin{tabular}{|c|c|c|c|c|c|c|c|c|c|c|c|c|c|}
\hline & & $\mathrm{Si}_{2} \mathrm{O} \%$ & $\mathrm{Al}_{2} \mathrm{O}_{3 \%}$ & $\mathrm{Fe}_{2} \mathrm{O}_{3 \%}$ & $\mathrm{MgO}^{2} \%$ & $\mathrm{CaO} \%$ & $\mathrm{Na}_{2} \mathrm{O} \%$ & $\mathrm{~K}_{2} \mathrm{O} \%$ & $\mathrm{TiO}_{2 \%}$ & $\mathrm{P}_{2} \mathrm{O}_{5 \%}$ & $\mathrm{MnO} \%$ & $\mathrm{Cr}_{2} \mathrm{O}_{3 \%}$ & LOI $\%$ \\
\hline \multirow[t]{7}{*}{ Ref. } & $\mathrm{A} 1$ & 53.10 & 18.81 & 8.25 & 1.59 & 0.37 & 0.06 & 0.65 & 1.43 & 0.12 & 0.08 & 0.04 & 15.40 \\
\hline & $\mathrm{A} 2$ & 49.92 & 18.15 & 6.63 & 3.73 & 0.48 & 0.09 & 0.94 & 1.49 & 0.10 & 0.08 & 0.02 & 18.20 \\
\hline & B & 53.60 & 27.84 & 1.75 & - & 2.03 & 0.03 & 0.40 & 1.10 & - & - & - & 12.98 \\
\hline & $\mathrm{C}$ & 38.90 & 27.50 & 5.07 & 0.57 & 1.40 & 2.39 & 10.30 & - & - & 0.03 & - & 13.70 \\
\hline & $\mathrm{D}$ & 55.76 & 20.60 & 0.70 & 0.20 & 0.30 & 2.00 & 0.30 & 1.15 & 0.012 & 0.02 & - & - \\
\hline & $\mathrm{E}$ & 46.75 & 28.34 & 1.79 & - & 1.42 & 0.51 & 0.30 & 1.20 & 0.42 & - & - & 19.72 \\
\hline & $\mathrm{F}$ & 54.22 & 16,92 & 8.12 & 2.93 & 5.90 & 0.37 & 0.41 & 0.25 & 0.43 & 0.38 & - & - \\
\hline \multirow[t]{6}{*}{$\mathrm{Sp}$} & $\mathrm{G} \neq$ & 49.88 & 37.65 & 0.88 & 0.13 & 0.03 & 0.21 & 1.60 & 0.09 & - & - & - & 12.45 \\
\hline & $\mathrm{H} \neq$ & 47.00 & 40.00 & - & - & - & - & - & - & - & - & - & 13.00 \\
\hline & $\mathrm{I}+$ & 48.67 & 9.45 & 2.70 & 8.50 & 15.84 & 2.76 & 2.76 & - & - & - & - & 14.2 \\
\hline & $\mathbf{j} \neq$ & 45.00 & 38.10 & 0.60 & - & - & - & - & 1.70 & - & - & - & 14.70 \\
\hline & $\mathrm{k} \neq$ & 67.07 & 26.50 & 0.50 & 0.19 & 0.03 & 1.50 & 3.10 & - & - & 1.20 & - & 12.51 \\
\hline & $\mathrm{L}^{*}$ & $40-48$ & $20-40$ & $1-4$ & $<5$ & $<5$ & $<3$ & $<3$ & - & - & - & - & $5-14$ \\
\hline
\end{tabular}

Ref $=$ Comparison with clay shale in Nigeria. $\quad \mathrm{Sp}=$ Industrial specifications.

$\mathrm{A} 1$ and A2 = Clay and Shale of study area respectively.

B = Awo-Omamma: Akpokodje et al., 1991

C = Afam Clay(Miocene): M.A. and L. C.Amajor,1991.

D = Okada Shale: Obrike S. E, Osadebe,C. C and Onyeobi, T. U. S, 2007.

$\mathrm{E}=$ Uyo Clay: Akpokodje, et al., 1991.

$\mathrm{F}=$ Clay bodies in parts of Eastern Dahomey Basin: M. E. Nton and A.A. Elueze, 2005.

$\mathrm{G}=$ Agricultural: Huber, 1985.

$\mathrm{H}=$ Pharmaceutical: Todd, 1975.

I = Bricks: Murray, 1960 .

$\mathrm{J}=$ Textile: Keller, 1964 . FAdopted from Okunlola 2010(Unpublished)

Elueze,2005.

*Adopted from akpokodje et al., 1991.

+Adopted from M. E. Nton and A. A.

$\mathrm{K}=$ Ceramics: Singer and Sonaja, 1971.

\section{Particle Size Analysis}

The results of the particle size analysis is presented in table 4 Generally, the particle size favours plasticity and mouldability. Particle size analysis showed that the average of $3.5 \%$ and $8.58 \%$ of the particles are greater than 63 microns in the clay and shale respectively.

The amount of fines, $(<63$ microns: clay + silt) varies from 90.00 to $96.4 \%$ in clays, while in the shale it varies from 84.40 to $94.50 \%$. The studied clay-shale is characterized by high proportion of clay size fractions. Clay size fractions range from 36 to $76 \%$ (Table 6). About $68 \%$ of the clay-shale samples have clay fractions between 51 to $76 \%$. By comparison the clay has more clay fractions than the shale. The clay fractions in the shale range from $36-68 \%$ while that of clay range from 47 to $76 \%$.

The high percentage of the clay- size fractions in some of the clay-shale favours its usability as filler and coating in paper, paint, rubber and cosmetic industries, however, the high iron content make it unsuitable where bright colour is desired. 
Table 4. Percentage of Clay: Silt: Sand Fractions

\begin{tabular}{lllll}
\hline SAMPLE CODE & CLAY \% & SILT \% & CLAY +SILT \% & FINE SAND \% \\
\hline 001 & 70.00 & 25.93 & 95.93 & 3.74 \\
$003 \mathrm{~A}$ & 47.00 & 46.07 & 93.07 & 5.91 \\
$003 \mathrm{~B}$ & 48.00 & 44.13 & 92.13 & \\
004 & 75.00 & 20.49 & 95.49 & 3.59 \\
007 & 73.00 & 21.45 & 94.45 & 4.67 \\
$009 \mathrm{~A}$ & 69.00 & 22.91 & 91.91 & 6.80 \\
$009 \mathrm{~B}$ & 68.00 & 14.51 & 92.51 & 6.70 \\
010 & 74.00 & 20.13 & 94.13 & 4.65 \\
012 & 76.00 & 18.95 & 94.95 & 4.25 \\
019 & 700.00 & 23.42 & 93.42 & 5.36 \\
020 & 70.00 & 23.87 & 93.87 & 5.62 \\
022 & 48.00 & 43.24 & 91.24 & 7.39 \\
025 & $64-00$ & 25.46 & 89.46 & 9.99 \\
$005^{*}$ & 68 & 24.36 & 92.36 & \\
$011^{*}$ & 45 & 45.95 & 90.95 & 6.83 \\
$015^{*}$ & 69.00 & 21.10 & 90.10 & 9.62 \\
$016^{*}$ & 46.00 & 47.80 & 93.80 & 5.50 \\
$018^{*}$ & 51.00 & 41.94 & 92.94 & 5.77 \\
$024 *$ & 36.00 & 47.40 & 83.40 & 15.64 \\
\hline
\end{tabular}

\section{Consistency Limits}

Table 5 shows the results the Atterberg Limits tests. The results of this tests showed that the Liquid Limits for clays and shale range between $(47.60-114.80 \%)$ and $(47.7-194 \%)$ respectively, while the plastic limits range for clays is $22.2-47.1 \%$ and that of shale is $18.5-77 \%$. Their plastic Indices also range from $15.8-77.3 \%$ and $16.7-116.3 \%$ respectively.

This result further showed that both clay and shale have wide range of Liquid, plastic limits and plastic indices. This wide variation is as a result of the variation in the mineralogy in the individual samples, the absence or presence of smectites, proportions of kaolinite to smectite, percentage of clay fraction and the proportion of non-clay minerals to the clay minerals (Tables 1). This is evident when sample 24 is compared with sample 10 . Sample 24 has lower clay fraction (36\%) and less amount of smectite (4.94) while sample 10 has $74 \%$ clay fraction and $12.72 \%$ smectite. As a result of this their Liquid Limits are $47.7 \%$ and 113.5 respectively. On the basis of the plastic limits the clay-shale falls within intermediate to high plasticity (Figure.5). Grimshaw (1971), showed that Plasticity Limits of 10 to $60 \%$ of clay materials are suitable for clays used for ceramic production. This shows the studied clay-shale is suitable for ceramics (Table 7).

Akpokodje et. al,(1991) has noted that two companies (Modern ceramics, Umuahia and Quality Ceramics Ltd, Uyo) utilized highly plastic clays deposits for the manufacture of ceramic wares by blending the clays with cohesion-less granular fine sand to reduce the plasticity, the expected excessive drying and firing shrinkages and the resultant internal cracking. The plasticity of Itu-Mbonuso/Iwere can be further reduced by Base Exchange during processing phase. The exchange base process can be carried out by blending the clay-shale with Lime $(\mathrm{CaO})$ or injected into the slurry. Au and Chae (1980) reported that the combination of additives such as lime $(\mathrm{CaO})$ and $\mathrm{Salt}(\mathrm{NaCl})$ significantly reduces the plasticity index and swelling potential.

Plot of plasticity indices against Liquid Limits (Figure.5), based on Casangrande's (1948) Chart indicated that the clay-shale are mostly inorganic and of medium to high compressibility. On the basis of liquid limit classification, the clay-shale is intermediate (35-50\%), high (50-70\%) very high (70-90\%) and extremely high $(>90 \%)$ plasticity.

Table 5. Results of Atterberg Limits test for Clay/Shale in Mbonuso/IwereArea

\begin{tabular}{lllllllll}
\hline $\begin{array}{l}\text { Sample } \\
\text { Code }\end{array}$ & $\begin{array}{l}\text { Liquid } \\
\text { Limit } \\
(\mathrm{WL})\end{array}$ & $\begin{array}{l}\text { Plastic } \\
\text { Limit } \\
\text { (PL) }\end{array}$ & $\begin{array}{l}\text { Plastic } \\
\text { Index (PI) }\end{array}$ & $\begin{array}{l}\text { Clay } \\
\text { Fraction \% }\end{array}$ & Activity & $\begin{array}{l}\text { Arbitrary Division } \\
\text { according to A }- \\
\text { Line }\end{array}$ & $\begin{array}{l}\text { BSCS } \\
\text { Classification }\end{array}$ & Remark \\
\hline $001 *$ & 73.2 & 32.20 & 41.0 & 70 & 0.59 & Clay & VCH & Inactive \\
\hline
\end{tabular}




\begin{tabular}{cllllllll}
\hline $003 \mathrm{a}^{*}$ & 75.8 & 45.3 & 30.5 & 47 & 0.65 & Silt & VMH & Inactive \\
$003 \mathrm{~b}^{*}$ & 74.8 & 47.1 & 27.7 & 48 & 0.58 & Silt & VMH & Inactive \\
$004^{*}$ & 75.6 & 23.2 & 52.5 & 75 & 0.70 & Clay & VCH & Inactive \\
$007^{*}$ & 77.9 & 23.3 & 54.6 & 73 & 0.75 & Clay & VCH & Inactive \\
$009 \mathrm{a}^{*}$ & 108.2 & 31.2 & 77.0 & 69 & 1.12 & Clay & ECH & Normal \\
$009 \mathrm{~b}^{*}$ & 106.0 & 32.3 & 73.7 & 68 & 1.08 & Clay & ECH & Normal \\
$010^{*}$ & 113.5 & 36.2 & 77.3 & 74 & 1.04 & Clay & ECH & Normal \\
$012^{*}$ & 114.8 & 38.2 & 76.6 & 76 & 1.01 & Clay & ECH & Normal \\
$019^{*}$ & 73.6 & 22.3 & 51.3 & 70 & 0.73 & Clay & VCH & Inactive \\
$020^{*}$ & 69.4 & 24.3 & 45.1 & 70 & 0.64 & Clay & CH & Inactive \\
$022^{*}$ & 50.9 & 35.1 & 15.8 & 48 & 0.33 & Silt & MH & Inactive \\
$025^{*}$ & 47.6 & 22.2 & 25.4 & 64 & 0.40 & Clay & CI & Inactive \\
$005^{* *}$ & 72.3 & 42.2 & 30.1 & 68 & 0.62 & Clay & VCH & Inactive \\
$011^{* *}$ & 113.2 & 57.5 & 55.7 & 45 & 1.24 & Silt & EMH & Normal \\
$015^{* *}$ & 53.0 & 34.5 & 18.5 & 69 & 0.50 & Clay & CH & Inactive \\
$016^{* *}$ & 194.0 & 77.7 & 116.3 & 46 & 2.53 & Silt & EMH & Active \\
$018^{* *}$ & 75.8 & 40.7 & 35.1 & 51 & 0.80 & Silt & VMH & Normal \\
$024^{* *}$ & 47.7 & 31.05 & 16.7 & 36 & 0.46 & Silt & MI & Inactive \\
\hline
\end{tabular}

$*$ CLAY, $* *$ SHALE

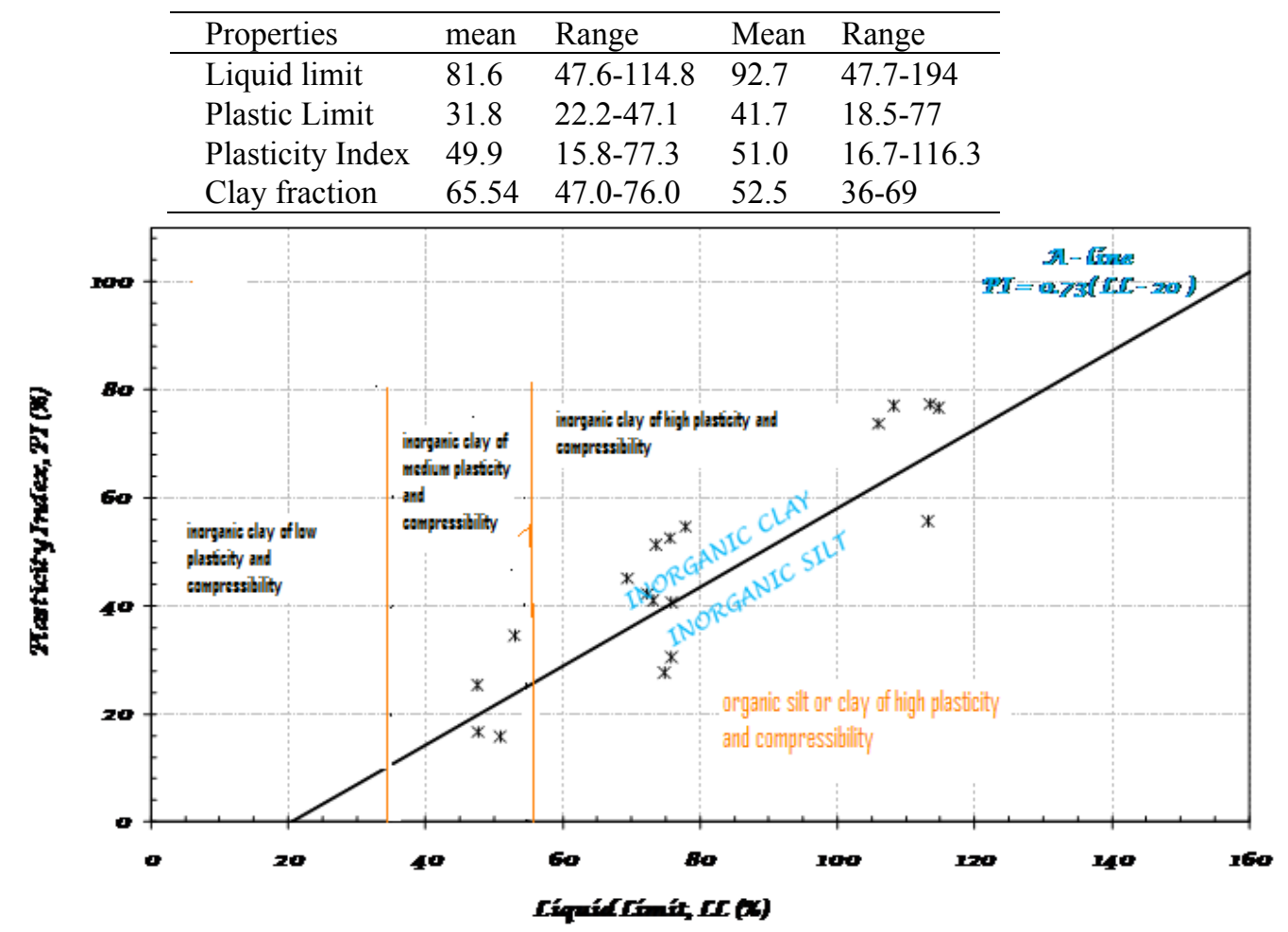

Figure 5. Plasticity Chart for Classification of Clay Bodies (After Casagrande, 1948)

\section{Firing Characteristics}

The results of the firing tests are presented in table 6. Percentage shrinkage and fired colour are some important characteristics that determine the suitability of clay material for various industrial uses. The degree of shrinkage on firing is dependent on mineralogical composition and other physical parameters.

\section{Fired Colour}

The fired colour is through orange to light brown and it depends on the amount of the oxides of iron and titanium. Generally, clays/shale with iron oxide exceeding 2-3\% will fire pinkish to reddish brown (Akpokodje, et al., 1991). Chemical test for all the samples showed that the iron oxide ranges from 5.73 to $9.52 \%$ and this responsible for the fired colour in the representative samples. In some ceramics, paper and paint industries the creamy, whitish fired colours are preferred in contrast to the reddish/brownish colours which in preferred in the 
pottery and brick industries. The fired colour of the studied clay-shale makes it unsuitable for production of paper. Any attempt to bleach the clay-shale to produce buff colour for paper production will greatly increase the cost of production.

\section{Fired Shrinkage}

The firing shrinkage tests revealed that the linear shrinkage is moderate between 4.8 to $6.6 \%$. This is due to the high plasticity resulting from the presence of smectites and high clay fractions low percentage of coarse fraction in the clays and shale. The result is internal cracking in the finished products. These cracks will lead to reduction in crushing strength of the finished products of bricks, ceramics and pottery. To reduce the fired shrinkage the clay-shale should be blended with cohesion-less fine sand in appropriate proportions. Robert Frome(1994) has stated that a clay body that meets all of a porter's need and shrinks no more than $12 \%$ is acceptable for most techniques. This showed that the Itu-Mbonuso/Iwere Clay-Shale is suitable for ceramics and structural bricks on the basis of its shrinkage.

Water Absorption Capacity: The values obtained on firing the clay and shale was all moderate, ranging from 10.12 to $13.48 \%$. This revealed the existence of internal cracking. Both linear shrinkage and water absorption capacity are influenced by the same factors. The more the plastic limits the more the linear shrinkage and water absorption capacity.

Loss on Ignition: The values obtained for loss on ignition range from 9.50 to $14.98 \%$. This results show that organic and volatile contents are moderate and they contributed to the moderate fired shrinkage values, water absorption capacity and apparent porosity of the clays and shale on firing. High volatile matter content particularly in the form of organic matters has adverse effects on industrial uses of clay because of unusually high shrinkage and resultant increase in porosity due to internal cracking. This leads to reduction of crushing strength of the finished products.

Table 6. Firing Characteristics of Itu-Mbonuso/Iwere Clay and Shale

\begin{tabular}{|c|c|c|c|c|c|c|c|}
\hline $\begin{array}{l}\text { Sample code } \\
\text { (IG) }\end{array}$ & $\begin{array}{l}\text { Colour } \\
\text { before firing }\end{array}$ & $\begin{array}{l}\text { Colour after } \\
\text { firing }\end{array}$ & $\begin{array}{l}\text { Fired shrinkage } \\
\% \text { at } 1200^{\circ} \mathrm{C}\end{array}$ & $\begin{array}{l}\text { Dry } \\
\text { shrinkage } \\
\% \text { at } 105^{\circ} \mathrm{C}\end{array}$ & $\begin{array}{l}\text { Water } \\
\text { absorption } \\
\text { capacity\% }\end{array}$ & $\begin{array}{l}\text { Loss on } \\
\text { ignition } \\
\% \\
\end{array}$ & Fireability \\
\hline 001 & Medium gray & Light brown & 6.6 & 12.9 & 11.25 & 12.57 & Good \\
\hline 003A & Yellow-gray & Grayish orange & 6.5 & 12.1 & 11.56 & 12.63 & Good \\
\hline 003B & $\begin{array}{l}\text { Medium } \\
\text { dark gray }\end{array}$ & $\begin{array}{l}\text { Moderate } \\
\text { reddish brown }\end{array}$ & 6.5 & 12.1 & 12.50 & 12.57 & Good \\
\hline 004A & Yellow gray & $\begin{array}{l}\text { Moderate } \\
\text { reddish orange }\end{array}$ & 6.6 & 12.9 & 11.05 & 12.89 & Good \\
\hline 007 & $\begin{array}{l}\text { Medium } \\
\text { dark gray }\end{array}$ & Light brown & 6.6 & 12.9 & 11.80 & 12.97 & Good \\
\hline 009A & Medium gray & Light brown & 5.7 & 12.9 & 11.24 & 13.76 & Good \\
\hline 009B & Medium gray & Light brown & 5.7 & 12.9 & 10.98 & 14.11 & Good \\
\hline 010 & Yellow gray & Grayish orange & 4.9 & 12.9 & 12.07 & 14.41 & Good \\
\hline 012 & $\begin{array}{l}\text { Medium } \\
\text { dark gray }\end{array}$ & $\begin{array}{l}\text { Moderate } \\
\text { reddish brown }\end{array}$ & 5.0 & 13.6 & 12.80 & 14.98 & Good \\
\hline 019 & $\begin{array}{l}\text { Yellowish } \\
\text { gray }\end{array}$ & $\begin{array}{l}\text { Moderate } \\
\text { reddish orange }\end{array}$ & 5.7 & 12.1 & 13.37 & 12.07 & Good \\
\hline 020 & $\begin{array}{l}\text { Medium } \\
\text { dark gray }\end{array}$ & Light brown & 5.7 & 12.1 & 11.85 & 12.14 & Good \\
\hline 022 & Medium gray & Light brown & 5.6 & 11.4 & 11.24 & 9.75 & Good \\
\hline $025^{*}$ & Medium gray & Light brown & 4.8 & 11.4 & 11.90 & 10.13 & Good \\
\hline $005^{*}$ & Medium gray & Light brown & 8.2 & 12.9 & 12.35 & 13.20 & Good \\
\hline $011^{*}$ & Yellow gray & Grayish orange & 9.1 & 13.6 & 12.72 & 14.41 & Good \\
\hline $015^{*}$ & $\begin{array}{l}\text { Medium } \\
\text { dark gray }\end{array}$ & $\begin{array}{l}\text { Moderate } \\
\text { reddish brown }\end{array}$ & 5.7 & 12.1 & 10.12 & 9.50 & Good \\
\hline $016^{*}$ & $\begin{array}{l}\text { Yellowish } \\
\text { gray }\end{array}$ & $\begin{array}{l}\text { Moderate } \\
\text { reddish brown }\end{array}$ & 10.0 & 14.3 & 12.79 & 14.47 & Good \\
\hline $018^{*}$ & $\begin{array}{l}\text { Medium } \\
\text { dark gray }\end{array}$ & Light brown & 8.2 & 12.9 & 13.48 & 12.70 & Good \\
\hline $024 *$ & Medium gray & Light brown & 4.8 & 11.4 & 11.83 & 10.36 & Good \\
\hline
\end{tabular}




\section{Economic Evaluation}

Study of the chemical compositions of the clay-shale showed that the clay-shale deposit can serve as a good source of raw material for low grade refractory raw material. The quality of the refractory product can, however, be improved or upgraded by screening the raw material to remove the silica in form of quartz and other non-clay fractions. Further upgrading can also be enhanced by bleaching with acid or by magnetic reduction of the iron oxide and titanium impurities (Ianicelli, 1971; Hughes, 1982). However, the high content of fluxes will affect the vitrification temperature. Further upgrading can be carried out by blending the beneficiated raw material with clay of high alumina content or pure alumina.

Further evaluation of the chemical compositions (S.R and A. R ratios, (Table 2) also indicated that the clay-shale is suitable for the manufacture of good quality cement and structural wares. The S.R and A. R ratios in combination with the plasticity limits (its mouldability) also make the clay-shale suitable for structural wares such as roofing tiles, drainage pipes, and sanitary wares.

The clay-shale is also suitable as raw material for the manufacture of ceramics burnt brick and Pottery wares. The medium to high plasticity of the study clay -shale makes it workable. Recommendation of clay materials with plasticity limits of 10 to $60 \%$ by Grimshaw, (1971) indicated the clay-shale meets the requirement for ceramics. However, because of the high plasticity and moderate linear fired shrinkage the clay-shale should be mixed with cohesion-less fine sand or silt (as filler) to minimise shrinkage and improve strength. The high concentration of fluxes in the clay and shale will favour early vitrifcation thereby leading to energy conservation in the industry. Further advantage of the lowering of the vitrification temperature ensues that the products are not porous and on cooling does not become glassy and brittle (Robert Fromme, 1994, Worall, 1969).

\section{Conclusions}

The studied clay-shale has similar chemical characteristics; however, the clay is marginally higher in iron oxide while the shale is higher in magnesia. The alumina content (average of $18.5 \%$ ) of clay- shale indicated that it can be used for low grade refractory bricks (Anon, 1972). The low grade quality can, however, be upgraded by blending with pure alumina and with clay of high alumina content or by screening of the clay to reduce the iron oxide and quartz as well as by chemical treatment. This latter treatment will, however, increase the production cost.

The AR and SR ratios are within the range considered for clay-shale suitability in the manufacture of high grade quality cement and structural wares (Abatan, 1993). The high iron and titanium oxide content which gave rise to orange to light brown colour on firing permits the use of the clay-shale for ceramics where buff colour is not a necessity, for example wall and floor tiles. The clay-shale is also suitable for manufacture of structural wares such as sewage pipes, roofing tiles and wall bricks. The clay-shale will require expensive refining to meet the specifications for Agricultural Pharmaceutical and textile industries.

Mineralogical analysis indicated that the most abundant and well distributed clay mineral is kaolinite (average of $30.19 \%$ ), a relatively small amount of smectites (average of 7.82\%) and palygorskite (average of $10.80 \%$ ), while the most abundant non-clay mineral, quartz, averages to $49.67 \%$.About $76 \%$ of the clay-shale samples have clay fraction between 50 to $76 \%$. Results of Atterberg limits determinations indicated that the plastic limits range is between $18.5 \%$ to $77 \%$. The plastic range of $10 \%$ to $60 \%$ recommended by Gimshaw (1971) showed that the studied clay-shale is mouldable and suitable for the production of ceramics. The orange to light brown fired colour makes the clay-shale unsuitable for high grade ceramics where buff colour is desired. Other fired characteristics, loss on ignition, water absorption and linear shrinkage are moderate. These moderate firing characteristic are as a result of small amount of smectites, organic matters and high percentage of clay fractions. This would result internal cracks in the finished products. It would therefore require blending with cohesion-less fine sand so that the finished products will have enough shears and crushing strength.

RecommendationFurther investigation is hereby recommended along the vertical profile with a view to finding out whether there is greater enhancement of the chemical characteristics with respect to reduction of iron oxide, increase in the alumina content and mineralogical variations. It is also necessary to further study the area where palygorskite and smectites are occurring together due to their importance as fuller's earth. Furthermore, palygorskite is an important clay mineral used in the manufacture of Maya Blue, a dye which is robust against harsh climatic conditions, acid, alkali and organic solvents. This dye remains persistent even when other dyes have faded away. Finally, the mineable tonnage of the deposit needed to be investigated by closely drilled holes.

\section{References}

Abatan, S. O., Odukoya, A. A., Ehimiyen, A. U., \& Bankole, B. O. (1993). Limestone and Shale investigation for 
cement manufacture at Somo, near Shagamu, Ogun State, Geological Survey of Nigeria, Abeokuta, Report, 110 p.

Akpokodje, E. G., Etu-Efeotor, J. O., \& Olurunfemi, B. N. (1991). The Composition and Physical Properties of some Ceramic and Pottery Clays of South- easternNigeria. Journal Min. Geol., 27(1), 4-7.

ANON. (1972). Kaolin in UK, English China Clay defends its lead in World Paper Industrial Minerals, 53, 9-29

AU, W., \& Chae, Y. S. (1980). Dynamic shear modulus of treated expansive soils. Journal of Geotechnical Engineering Division, 106(GT3), 255-273.

Burke, K., Dessauvagie, C., \& Whiteman, A. J. (1970). Geological history of the Benue Valley and Adjacent areas. In T. F. J. Dessauvagie, \& A. J. Whiteman (Eds.), African Geology. University of Ibadan press, Nigeria.

Casagrande, A. (1948). Classification and identification of soils. Trans. A. S. C. E., 113, 901- 992.

Dorothy, C. (1970). Clay Minerals: Guide to their X-ray identification. Pub. The Geological Society of America INC.

Grant. (1971). South Atlantic, Benue trough and Gulf of Guinea Cretaceous triple Junction. Geol. Soc.Amer. Bull. 82, 2295-2298. http://dx.doi.org/10.1130/0016-7606(1971)82[2295:SABTAG]2.0.CO;2

Grim, R. E. (1962). Applied Clay Mineralogy, McGraw Hill, New York.

Grimshaw, R.W. (1971). The Chemistry and Physics of Clays and Allied Ceramic Materials (3rd ed.). Ernest Benn Limited, 8801-8802.

Hughes, J. C. (1982). High gradient magnetic separation of soil clays in Nigeria, Brazil and Columbia: The Interrelationship of Iron and Magnesium extraction by acid Ammonium Oxalate and Carbon. Journal Soil Sci., 33, 501-519.

Ianicelli, J. (1976). High extraction magnetic filtration of kaolin. Clays Clay Miner., 24, 64-68. http://dx.doi.org/10.1346/CCMN.1976.0240203

Joint Committee on Powder Diffraction Standard (JCPDS) (1974, 1980). Selected Powder diffraction Data for Minerals; ed. L. G. Barry, Pub. JointCommittee on Powder Diffraction Standard; Philadephia.

Kogbe C. A. (1975). Paleogeographic History of Nigeria from Albian Times. Geology of Nigeria; Elisabeth Publishing Company of Nigeria. 237- 251.

Murray, H. H. (1960). Clay industrial minerals and rocks (3rd ed.). Publ. Am. Inst. of Mining Metall. and Petroleum Engineers

Nton, M. E., \& Elueze, A. A. (2005). Compositional characteristics and Industrial assessment of sedimentary clay bodies in parts of eastern Dahomean basin, south-western Nigeria. Journal Min. Geol., 41(2), 175-183.

Obaje, N. G. (2009). Geological and Mineral Resources of Nigeria. Lecture Notes in Earth Sciences, Series, 120, 1.

Obrike, S. E., Osadebe, C. C., \& Onyeobi, T. U. S. (2007). Mineralogical geochemical, physical and industrial characteristics of shale from Okada area, South-Western Nigeria. Journal of Nigerian Mining and Geosciences Society, 43(2), 109-116.

Okunlola, O. A. (2008). Compositional characteristics and functional Industrial application of Itakpe Clay Occurrence, Central Nigeria. Eurp. Journal of Sc. Research, 19(3), 453-461.

Robert, F. (1994). Basic Notes on Clays and Clay Bodies. Retrieved from $\mathrm{http} / / /$ cavemanchemistry.com/oldcave/projects/pottery/basic_clays.html

Short, K. C., \& Stauble, A. J. (1967). Outline of Geology of Niger Delta. Bull. Amer. Assoc. petr. Geol. 54(5), 761-779.

Simpson, A. (1955). The Nigerian Coal Field: The Geology of parts of Onitsha.

\section{Copyrights}

Copyright for this article is retained by the author(s), with first publication rights granted to the journal.

This is an open-access article distributed under the terms and conditions of the Creative Commons Attribution license (http://creativecommons.org/licenses/by/3.0/). 